\title{
As "relações" entre o PET Vigilância em Saúde e o Núcleo de Epidemiologia Hospitalar
}

\author{
Marcos M. B. dos Santos, MSc. \\ Mestre em Ciéncias Sociais (PUCRS) e Doutorando em Sociologia (UFRGS) \\ Professor de Sociologia (Unisc) \\ Coordenador do PET Vigiláncia Saúde (Unisc)
}

O Programa de Educação para o Trabalho pela Saúde (PET) é um programa do Ministério da Saúde com a finalidade de induzir mudanças no processo de formação na área da saúde. Os pilares do programa são as metodologias de aprendizagem ativa como os grupos tutoriais $e$ a interaçāo ensino-serviço. Outras modalidades de PET Saúde já foram desenvolvidas com parceria entre a Unisc e a Secretaria Municipal de Saúde de Santa Cruz do Sul (SCS). O PET Saúde/ Vigilància terá duraçäo de dois anos (agosto de 2010 a julho de 2012). O projeto é constituido por trés grupos tutoriais voltados para o estudo e a pesquisa de aspectos epidemiológicos da tuberculose, da saúde do trabalhador e da leptospirose em SCS. Cada grupo é constituido por um tutor acadèmico (professor universitário), dois preceptores (profissionais com $3^{\circ}$ grau) que atuam na rede de saúde básica e oito estudantes (quatro para cada preceptor), totalizando, portanto, três tutores acadêmicos, seis preceptores e 24 acadèmicos. A dedicação é de oito horas semanais de ensino/trabalho. O pilar é a multiprofissionalidade (enfermeira, bióloga, médico, sociólogo, veterinário, farmacêutico), juntamente com graduandos de diferentes cursos (Enfermagem, Farmácia, Fisioterapia, Medicina, Nutrição, Odontologia e Psicologia). Essa fundamentaçăo é essencial para um aprendizado com troca de experiências e incentivo para a busca ativa do conhecimento cientifico e aplicabilidade na experiência profissional. O objetivo geral é a educação pelo trabalho em saúde com ênfase nas açōes de vigilància em saúde no ầmbito municipal. As es- tratégias de atuação são de acordo com as diretrizes da Vigilância em Saúde do Sistema Único de Saúde (SUS), contribuindo para o conhecimento e compreensão das condiçōes de vida e trabalho das pessoas que residem no municipio, bem como das formas de organização e de atuaçăo dos diversos órgãos e agências (governamentais e não-governamentais). Os resultados esperados das açōes do PET/Vigilància irão permitir a análise dos riscos ambientais à saúde e à qualidade de vida, a análise das condiçōes de saúde da populaçăo e dos seus determinantes sociais, o mapeamento dos fatores de risco e proteçâo à saúde da populaçāo e o monitoramento de situaçōes que configurem risco de emergências epidemiológicas. O graduando se insere na realidade da situação da saúde e faz sua iniciação em pesquisa comprometida com as necessidades sociais e os principios do SUS com aplicabilidade imediata sobre a realidade sanitária local, O PET/Vigilância incentiva a responsabilidade e o privilégio de participar de um movimento de transformaçâo para a formação/atualizaçāo dos profissionais em saúde, com vistas a um processo de aprendizagem ampla: generalista, humanista, cientifica, critica e reflexiva - pautada nas necessidades de saúde da populaçăo e pela realidade do sistema de serviços de saúde. Portanto, o "aprender fazendo" e as metodologias ativas de aprendizagem por meio de açōes formativas contribuirão para a formação de profissionais sensiveis para as necessidades básica de saúde e das relaçōes que se estabelecem entre os serviços de saúde, os usuários, as instâncias decisórias e a universidade. 